\title{
EFEK INDUKSI LPS TERHADAP JUMLAH OSTEOBLAS PADA RESORPSI TULANG ALVEOLAR TIKUS PUTIH JANTAN (Rattus norvegicus) GALUR SPRAGUE DAWLEY
}

\author{
Ketut Virtika Ayu \\ Bagian Ortodonsia, Fakultas Kedokteran Gigi, Universitas Mahasaraswati Denpasar \\ E-mail : drg.virtika@yahoo.com
}

\begin{abstract}
In recent years, a growing number of Indonesian people perform maintenance on the oral cavity including periodontitis if not treated will cause alveolar bone resorption that would lead to bone fractures, tooth loss and the difficulty of post-orthodontic treatment. The main factors that cause periodontitis is bacterial plaque. The bacteria that most contribute to the onset periodontitis is Gram-negative bacteria that will release products including biologically active endotoxin or lipopolysaccharide (LPS) that causes inflammation and induce cellular events in periodontal tissues, especially in the alveolar bone. This stimulation becomes an induced activation function and activity of osteoclasts increased and decreased number of osteoblasts, which in turn will lead to the destruction of the alveolar bone inorganic minerals and alveolar bone resorption. Essential to these problems, the researcher wanted to know more about the decrease the number of osteoblasts in alveolar bone resorption in white male rats (Rattus norvegicus), Sprague Dawley strain induced by LPS. This study is a preliminary study using 6 white male rats Sprague Dawley strain were divided into two groups: control group (normal rats were not induced LPS) and the treatment group (induced by LPS) using Post Test Only Control Group Design. Results showed that the average number of osteoblasts in the treatment group (37 cells per five field of view) is lower than the control group (76 cells per five field of view). This preliminary study concluded that decreased the number of osteoblast in alveolar bone resorption in white male rats Sprague Dawley strain induced by LPS.
\end{abstract}

Keywords : Osteoblast, alveolar bone resorption, LPS

\section{PENDAHULUAN}

Resorpsi tulang banyak ditemui pada penyakit periodontal, rheumatoid arthritis, osteoporosis dan tumor. Pada bidang kedokteran gigi, resorpsi tulang dapat mengakibatkan tulang mudah fraktur, gigi mudah tanggal, dan sulitnya fase perawatan dan retensi pasca perawatan ortodontik.

Penyakit periodontal merupakan penyakit umum dan tersebar luas di masyarakat, bisa menyerang anakanak, orang dewasa maupun orang tua. Salah satu bentuk penyakit periodontal adalah keradangan yang menyerang jaringan periodontal, dapat hanya mengenai gingiva yang disebut dengan gingivitis atau mengenai jaringan periodontal yang lebih luas (ligamen periodontal, sementum dan tulang alveolar) yang disebut dengan periodontitis. ${ }^{1}$

Faktor penyebab utama periodontitis yaitu plak bakteri. ${ }^{2}$ Sifat penyakit periodontal ini kurang memberi keluhan rasa sakit, kecuali jika ada komplikasi yang akut, sehingga sering ditemukan dalam keadaan lanjut. ${ }^{1}$ Bakteri yang paling banyak berperan terhadap timbulnya periodontitis adalah bakteri Gram negatif, diantaranya yaitu Porphyromonas gingivalis, Actinobacillus actinomycetemcomitans, Prevotella intermedia, dan Bacteriodes forsythus. Bakteri Gram negatif anaerob ini, mengeluarkan produk-produk diantaranya endotoksin biologi aktif atau lipopolisakarida (LPS) yang menyebabkan aktivitas biologis sehingga terjadi keradangan yang selanjutnya toksin ini dapat menginduksi kejadian-kejadian seluler di jaringan periodontal khususnya pada tulang alveolar. Rangsangan ini menjadi sebuah induksi pengaktifan fungsi dan aktivitas osteoklas yang meningkat dan penurunan jumlah osteoblas, yang selanjutnya akan menyebabkan rusaknya mineral anorganik dari tulang alveolar dan terjadilah resorpsi tulang alveolar. Apabila proses resorpsi ini tidak terkendali maka tulang alveolar yang mendukung gigi akan berkurang dan menyebabkan gigi goyang dan akibat yang lebih fatal lagi adalah rasa sakit dan lepasnya gigi dari soketnya. ${ }^{3}$

LPS adalah salah satu penyebab terjadinya kelainan periodonsium. Bahan ini merupakan struktur utama dinding sel bakteri Gram negatif yang berfungsi untuk integritas struktur bakteri dan melindungi bakteri dari sistem pertahanan imun hospes. LPS bersifat endotoksin yang menginduksi diproduksinya faktor lokal yaitu sitokin proinflamatori seperti interleukin- $1 \alpha$ (IL-1 $\alpha$ ), IL-1 $\beta$, IL-6, tumor necrosis factor- $\alpha$ (TNF- $\alpha$ ) dan eikosanoid yaitu prostaglandin (PGE2). Prostaglandin dan sitokin proinflamatori mengakibatkan terjadinya destruksi jaringan periodonsium, dengan cara menstimulasi pembentukan dan peningkatan aktivitas osteoklas serta penurunan jumlah dan aktivitas osteoblas. ${ }^{4}$

Tulang secara kontinyu dibentuk oleh osteoblas dan secara kontinyu diresorpsi ketika osteoklas menjadi aktif. Osteoblas dijumpai di permukaan luar tulang dan di rongga-rongga tulang. Sejumlah kecil aktivitas osteoblastik terjadi secara kontinyu di semua jaringan tulang yang hidup sehingga sedikitnya sejumlah tulang baru dibentuk secara konstan. ${ }^{5}$

Mendasar pada permasalahan tersebut, maka peneliti ingin mengetahui lebih lanjut tentang penurunan jumlah osteoblas pada resorpsi tulang alveolar tikus putih jantan (Rattus norvegicus) galur Sprague Dawley yang diinduksi LPS. 
Jaringan periodontal tersusun dari komponen matriks ekstraseluler yaitu kolagen yang berperan dalam proses regenerasi dan kerusakan jaringan. Kolagen interstisial jaringan periodontal berfungsi untuk penyembuhan dan pembentukan jaringan baru. ${ }^{6}$ Jaringan periodontal terdiri atas Dento gingival junction, sementum, ligamen periodontal dan tulang alveolar. ${ }^{7}$

Tulang alveolar adalah tulang yang berongga, tepatnya di samping ligamen periodontal. Lapisan luar terdiri dari compact bone, lapisan tengah spongiosa bone, serta lapisan dasar adalah alveolar bone. Lapisan luar (compact bone) dan lapisan tengah (spongiosal trabecular bone) tersusun atas lamela-lamela dengan sistem havers. ${ }^{8}$

Tulang adalah jaringan ikat khusus yang terdiri atas materi antarsel berkapur, yaitu matriks tulang dan tiga jenis sel : osteosit, yang terdapat di rongga-rongga (lakuna) di dalam matriks; osteoblas, yang menyintesis unsur organik matriks, dan osteoklas, yang merupakan sel raksasa multinuklear yang terlibat dalam resorpsi dan remodeling jaringan tulang. ${ }^{9}$

Penyakit periodontal adalah suatu inflamasi kronis pada jaringan pendukung gigi (periodontium). Penyakit periodontal dapat hanya mengenai gingiva (gingivitis) atau dapat menyerang struktur yang lebih dalam (periodontitis). Gambaran klinis yang membedakan antara gingivitis dan periodontitis adalah ada tidaknya kerusakan jaringan periodontal destruktif umumnya dihubungkan dengan keberadaan dan atau meningkatnya jumlah bakteri patogen spesifik dan adanya kerusakan tulang. ${ }^{10}$

Pada periodontitis, terdapat plak mikroba Gram negatif yang berkolonisasi dalam sulkus gingiva (plak subgingiva) dan memicu respon inflamasi kronis. Sejalan dengan bertambah matangnya plak, plak menjadi lebih patogen dan respon inflamasi host berubah dari keadaan akut menjadi keadaan kronis. Apabila terjadi kerusakan jaringan periodontal, akan ditandai dengan terdapatnya poket. Semakin dalamnya poket, semakin banyak terdapatnya bakteri subgingiva yang matang. Hal ini dikarenakan poket yang dalam terlindungi dari pembersih mekanik (penyikatan gigi). ${ }^{11}$

Meskipun penyakit periodontal diawali oleh kolonisasi bakteri pada permukaan gigi dan sulkus gingiva, respon tubuh terhadap infeksi tersebut mempunyai peranan dalam kerusakan jaringan ikat dan tulang. Patogenesis penyakit periodontal merupakan suatu proses inflamasi yang melibatkan respon imun bawaan (innate immunity) dan imun adaptif / didapat (adaptive immunity). ${ }^{12}$ Sel-sel fagosit, seperti polimorfonuklear neutrofil, monosit, dan makrofag yang merupakan sel-sel imun bawaan, memicu pelepasan mediator-mediator kimia seperti sitokin yaitu TNF dan IL yang mengaktifkan berbagai sistem seperti sistem komplemen dan respon fase akut. ${ }^{13}$

Baik sistem imun dan metabolisme tulang akan melibatkan regulasi sitokin dan molekul-molekul lainnya dalam jumlah banyak. Saat ini regulasi dari molekul-molekul tersebut dikaitkan dengan Receptor Activator of Nuclear Factor Kappa B Ligand (RANKL), Receptor Activator of Nuclear Factor Kappa B (RANK) dan Osteoprotegerin (OPG). ${ }^{14}$
Macrophage Colony Stimulating Factors (M$\mathrm{CSF}$ ), adalah salah satu sinyal molekul paling awal yang diidentifikasi pada perkembangan dan aktivasi osteoklas. ${ }^{14}$ Sel-sel prekursor osteoklas berasal dari hematopoietic stem cell yang berdiferensiasi menjadi colony forming unit for granulocytes and macrophages (CFU-GM) mengekspresikan RANKL dengan stimulasi oleh M-CSF. ${ }^{12}$ M-CSF dihasilkan terutama oleh osteoblas atau sel stromal sumsum tulang dan mengikat reseptor pada pre-osteoklas yang disebut cFms anggota dari tyrosine kinase receptor. ${ }^{14}$ RANKL adalah mediator kunci terjadinya pembentukan osteoklas. RANKL merupakan membrane-bound protein adalah anggota dari TNF (tumor necrosis factor) yang diekspresikan oleh bermacam sel seperti osteoblas, fibroblas dan sel limfosit. Pada metabolisme tulang normal, RANKL diekspresikan oleh osteoblas. ${ }^{14}$ Pada inflamasi, RANKL juga diekspesikan oleh sel imun adaptif seperti sel limfosit $\mathrm{T}$ dan sel limfosit $\mathrm{B}$ yang teraktivasi. $^{12}$ Ekspresi RANKL juga diregulasi oleh modulator metabolisme tulang seperti paratiroid hormon, vitamin D dan IL-11 (Interleukin-11). Ikatan RANKL dengan reseptornya yaitu RANK mengaktifkan osteoklastogenesis. $^{14}$

OPG adalah inhibitor alami untuk menghambat ikatan RANKL dengan RANK. Reseptor RANK terdapat pada pre-osteoklas maupun pada osteoklas. OPG merupakan pecahan dari TNF receptor-like molecule dengan bertindak sebagai perangkap dan memblokir ikatan RANKL dan RANK mencegah osteoklastogenesis. OPG diproduksi oleh sel-sel ligamen periodontal, fibroblas gingiva dan sel-sel epitel dan ekspresi OPG di modulasi oleh sitokin inflamasi. Hambatan ikatan RANKL dengan RANK oleh OPG dapat memicu apoptosis dari osteoklas sehingga menurunkan proses resorpsi tulang. ${ }^{14}$

Prinsip inflamasi yang menyebabkan kehilangan tulang pada periodontitis dan ditambah dengan aktivitas osteoklas, tanpa diikuti dengan pembentukan tulang oleh osteoblas. Osteoklas adalah multisel yang berasal dari monosit atau makrofag dan merupakan sel penting yang berperan terhadap resorpsi tulang. Penelitian tentang kekurangan osteoklas pada tikus, menunjukkan peran sangat penting dari sel dalam resorpsi tulang. Osteoklas multinuklear telah menunjukkan resorpsi tulang alveolar pada hewan dan manusia akibat penyakit periodontitis. Pembentukan osteoklas didorong oleh keberadaan sitokin pada jaringan periodontal yang telah terinflamasi dan terjadi secara lokal pada daerah permukaan tulang melalui beberapa mekanisme. Fibroblas dan limfosit (sel T dan sel B yang teraktivasi) akan memproduksi RANKL distimulasi oleh adanya sitokin pro-inflamasi. Sitokin ini pula secara langsung mengaktifkan monosit berdiferensiasi menjadi makrofag dan juga pre-osteoklas untuk selanjutnya menjadi osteoklas matur melalui ikatan RANKL dengan RANK. ${ }^{4,12,14}$

Faktor yang berpengaruh pada kerusakan tulang adalah bakteri dan host. Produk plak bakteri meningkatkan diferensiasi sel progenitor tulang menjadi osteoklas dan merangsang sel gingiva untuk mengeluarkan suatu mediator yang memicu terjadinya hal tersebut. Produk plak dan mediator inflamasi untuk 
menghambat kerja dari osteoblas dan menurunkan jumlah sel-sel tersebut. ${ }^{15}$ Jadi, aktivitas resorpsi tulang meningkat, sedangkan proses pembentukan tulang terhambat sehingga terjadilah kehilangan tulang.

Mekanisme Lps Dalam Resorpsi Tulang Alveolar

LPS merupakan struktur utama dinding sel bakteri Gram negatif yang berfungsi untuk integritas struktur bakteri dan melindungi bakteri dari sistem pertahanan imun host terdiri atas lipid A, antigen $\mathrm{O}$ dan oligosakarida yang terikat bersama. Lipid A dapat memicu respon inflamasi. LPS binding protein (LBP) adalah reaktan pada fase akut yang disintesis oleh hepatosit yang mengkatalase LPS, sehingga LPS dapat terikat pada reseptornya kemudian terikat pada membran Cluster of Differentiation-14 (CD14). LPS bersifat endotoksin karena LPS mengikat reseptor CD14 yang merupakan reseptor permukaan sel pada monosit atau makrofag. LPS mampu mengaktivasi sitem imun bawaan dengan menstimulasi Toll-Like Receptor-4 (TLR4) yang merupakan protein pada permukaan sel yang dapat mengenali produk bakteri. ${ }^{16}$ LPS berpengaruh pada jaringan periodontal seperti makrofag, limfosit, fibroblas dan osteoblas / osteoklas. ${ }^{16}$

Aktivasi reseptor CD14 mengaktivasi monosit dan sel endotel melalui jalur TLR4-dependent menghasilkan molekul / sitokin pro-inflamasi seperti IL1, TNF dan prostaglandin $\mathrm{E}_{2}\left(\mathrm{PGE}_{2}\right)$ dan IL-6. Molekulmolekul ini kemudian memproduksi platelet activation factor (PAF), aminase bioaktif (bradikinin dan histamin) dan prostaglandin. $\mathrm{PGE}_{2}$ dan sitokin proinflamasi dapat memicu osteoklastogenesis. ${ }^{16}$ Osteoklastogenesis akan meningkatkan jumlah osteoklas dan akan menurunkan jumlah osteoblas (Gambar 1). ${ }^{4}$

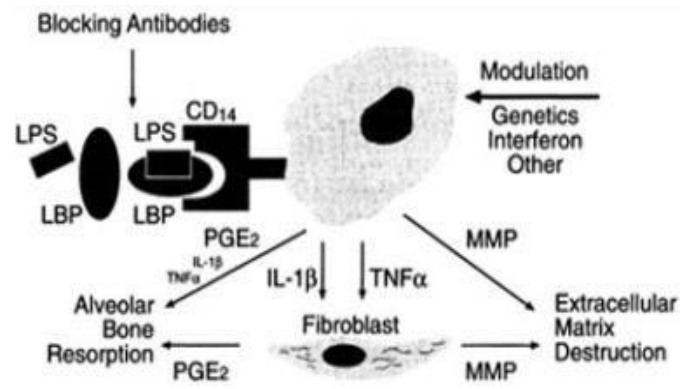

Gambar 1. Mekanisme LPS dalam resorpsi tulang alveolar. ${ }^{17}$

\section{BAHAN DAN METODE}

Penelitian ini merupakan penelitian pendahuluan dengan rancangan penelitian Post Test Only Control Group Design yang menggunakan hewan coba tikus putih jantan (Rattus norvegicus) galur Sprague Dawley sebanyak 6 ekor yang dibagi menjadi dua kelompok yaitu kelompok kontrol (tikus normal tidak diinduksi LPS) dan kelompok perlakuan yang diinduksi LPS (Gambar 2).

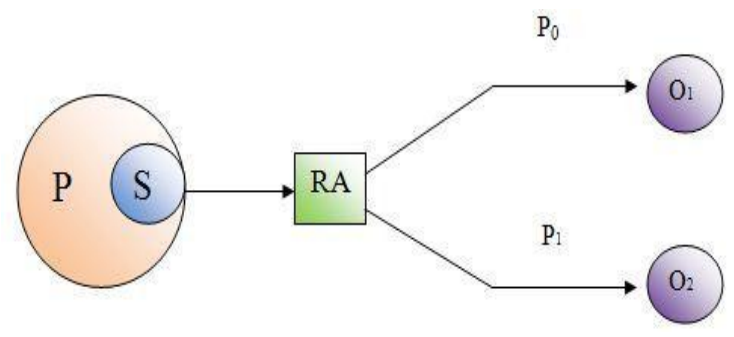

Gambar 2. Rancangan penelitian

Keterangan :

$\mathrm{P} \quad=$ Populasi (tikus dengan periodontitis)

$\mathrm{S}=$ Sampel penelitian

$\mathrm{RA}=$ Random Alokasi

$\mathrm{P}_{0}=$ Kontrol (tikus normal tidak diinduksi LPS)

$\mathrm{P}_{1}=$ Perlakuan (diinduksi dengan LPS)

$\mathrm{O}_{1}=$ Nilai observasi jumlah osteoblas pada kelompok $\mathrm{P}_{0}$

$\mathrm{O}_{2}=$ Nilai observasi jumlah osteoblas pada kelompok $\mathrm{P}_{1}$

Tempat penelitian dilakukan di Laboratorium Penelitian dan Pengujian Terpadu Universitas Gajah Mada (LPPT-UGM) Yogyakarta pada bulan Maret Mei 2014.

LPS E.coli merupakan endotoksin dari bakteri gram negatif E.coli yang didapat dari Sigma Aldrich (LPS E.coli 0111:B4, L2630) dengan bentuk sediaan bubuk kemudian diencerkan dengan PBS (Phosphate Buffer Saline) steril dengan dosis $5 \mu \mathrm{g}$ dalam $0,05 \mathrm{ml}$ PBS.

Osteoblas adalah jumlah osteoblas pada tulang alveolar berupa sel berinti satu dan pipih yang berada di endosteum, dengan sitoplasma yang basofilik dibuat preparat atau sediaan mikroskopis dengan pengecatan HE (Harris Hematoxylin - Eosin) dan dilihat pada lima lapang pandang dengan menggunakan mikroskop elektrik Olympus CX35 dengan perbesaran 400x.

Hewan coba yang digunakan adalah tikus putih jantan galur Sprague Dawley dengan berat 180-200 gr berumur 2-3 bulan diadaptasikan selama satu minggu di tempat penelitian untuk penyesuaian dengan lingkungan. Bedding setiap 3 hari diganti dan tikus-tikus tersebut diberikan konsumsi makanan standar $A D$ II pellets dan air minum RO (Reverse Osmosis) ad libitum.

Pada kelompok $\mathrm{P}_{0}$ tidak dilakukan induksi LPS sedangkan kelompok $\mathrm{P}_{1}$ dilakukan induksi LPS pada sulkus gingiva pada daerah bukal incisivus sentral rahang bawah tikus putih jantan galur Sprague Dawley sebanyak $5 \mu \mathrm{g}$ dalam $0,05 \mathrm{ml}$ PBS satu kali sehari selama delapan hari dimana sebelumnya tikus dianestesi dengan kombinasi Ketamine $80 \mathrm{mg} / \mathrm{kgBB}$ dan Xylazine (10 $\mathrm{mg} / \mathrm{kgBB})$ yang disuntikkan pada daerah kaki belakang sebelah kiri di musculus quadricep / tricep.

Hari ke-9 tikus dieutanasia dengan chloroform secara inhalasi. Kapas dibasahi chloroform diletakkan dalam toples berukuran sedang (diameter $20 \mathrm{~cm}$ ) kemudian hewan dimasukkan ke dalam toples dan toples ditutup hingga tikus mati. Tikus difiksasi pada meja kerja lalu dilakukan pengambilan jaringan tulang mandibula dengan scalpel atau gunting dan ditempatkan 
dalam wadah tertutup berisi buffer formalin $10 \%$ dan dikirim ke laboratorium untuk dibuat sediaan mikroskopis. Sisa dari tikus kemudian diinsenerator di LPPT Unit IV UGM.

\section{HASIL DAN PEMBAHASAN}

Hasil penelitian pendahuluan terhadap tikus putih jantan galur Sprague Dawley tampak perbedaan jumlah osteoblas (anak panah) pada kelompok kontrol dan kelompok perlakuan secara histologis yang dapat dilihat pada Gambar 3 dan 4

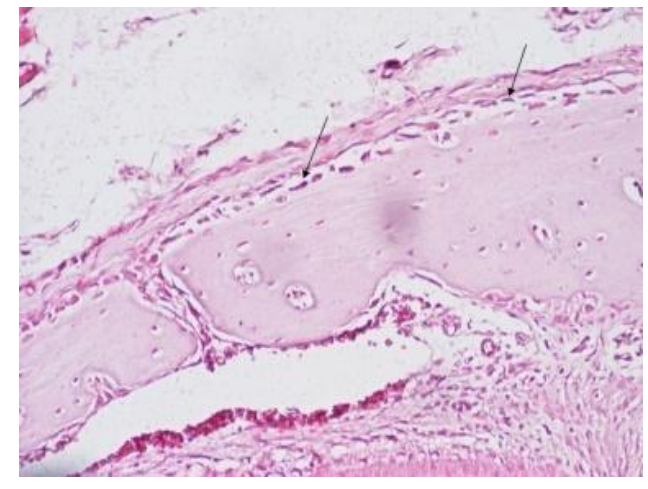

Gambar 3. Jumlah osteoblas pada kelompok kontrol

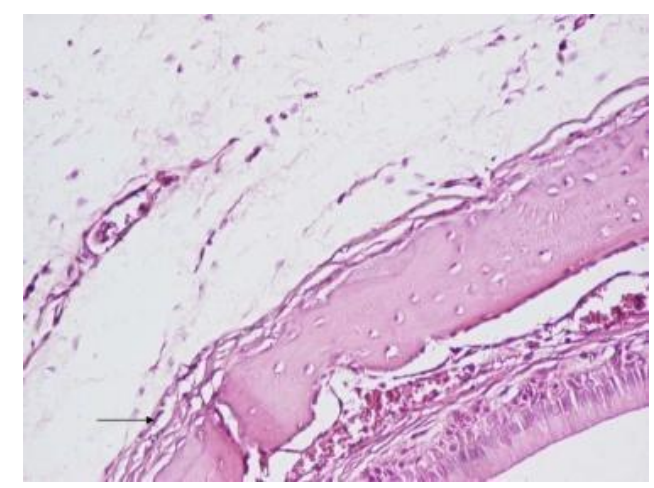

Gambar 4. Jumlah osteoblas pada kelompok perlakuan (diinduksi LPS selama delapan hari)

Pada gambaran histologis tersebut di atas terlihat adanya perbedaan jumlah osteoblas pada kelompok kontrol dibandingkan dengan kelompok perlakuan. Rerata jumlah osteoblas pada kelompok perlakuan lebih sedikit dibandingkan dengan kelompok kontrol. Pada kelompok kontrol menggunakan 3 ekor tikus putih jantan galur Sprague Dawley didapatkan rerata 76 sel per lima lapang pandang. Pada kelompok perlakuan menggunakan 3 ekor tikus putih jantan galur Sprague Dawley didapatkan rerata 37 sel per lima lapang pandang.

Adanya penurunan osteoblas pada kelompok perlakuan disebabkan adanya induksi LPS. LPS bersifat endotoksin karena LPS mengikat reseptor CD14 yang merupakan reseptor permukaan sel pada monosit atau makrofag. LPS mampu mengaktivasi sitem imun bawaan dengan menstimulasi Toll-Like Receptor-4 (TLR4) menghasilkan molekul / sitokin pro-inflamasi seperti IL-1, TNF dan prostaglandin $\mathrm{E}_{2}\left(\mathrm{PGE}_{2}\right)$ dan IL6. Molekul-molekul ini kemudian memproduksi platelet activation factor (PAF), aminase bioaktif (bradikinin dan histamin) dan prostaglandin. $\mathrm{PGE}_{2}$ dan sitokin proinflamasi dapat memicu osteoklastogenesis. ${ }^{16}$ Osteoklastogenesis akan meningkatkan jumlah osteoklas dan akan menurunkan jumlah osteoblas. ${ }^{4}$

\section{SIMPULAN}

Berdasarkan penelitian pendahuluan yang telah dilakukan dapat disimpulkan bahwa terdapat penurunan jumlah osteoblas pada resorpsi tulang alveolar tikus putih jantan galur Sprague Dawley yang diinduksi LPS.

\section{DAFTAR PUSTAKA}

1. Kurniawati A. Hubungan kehamilan dan kesehatan periodontal. J. Biomed 2005; II(2): 43-51.

2. Fitria E.. Kadar IL-1B dan IL-8 sebagai penanda periodontitis, faktor resiko kelahiran prematur. Jurnal PDGI 2006; 56(2): 60-4.

3. Amin MN, Meilawaty Z, Sandrasari D. Prospek probiotik dalam pencegahan agresivitas resorpsi osteoklastik tulang alveolar yang diinduksi lipopolisakarida pada penyakit periodontal. Dentika Dental Journal 2010; 15(2): 150-3.

4. Indahyani DE, Santoso A, Utoro T, Soesatyo MH. fish oil regulates bone sialoprotein and osteopontin in alveolar bone resorption. Naskah Lengkap Joint Scientific Meeting in Dentistry (JSMiD) 2010; Surabaya 15 - 16 Mei 2010.

5. Guyton AC, Hall JE. Buku Ajar Fisiologi Kedokteran, Irawati, Ramadhani D, Indriyani F, Dany F, Nuryanto I, Rianti SSP, Resmisari T, Suyono YJ (penterjemah), Ed 11, Jakarta: EGC; 2008. h. 1032-5.

6. Wahyukundari MA. Perbedaan kadar matrix metalloproteinase-8 setelah scaling dan pemberian tetrasiklin pada penderita periodontitis kronis. Jurnal PDGI 2009; 58(1): 1-6.

7. Carranza FA. The periodontal disease. In: Carranza FA, Forrest JL, Kenney EB, Klokkevold, PR, Newman MG, Novak MJ, Preshaw P, Taeki, HH. Carranza's. Clinical Periodontology. $10^{\text {th }}$ Ed. St. Louis. Saunder Elsevier; 2006. h. 154-7.

8. Newman MG. The normal periodonsium. In : Carranza FA, Forrest JL, Kenney EB, Klokkevold PR, Newman MG, Novak MJ, Preshaw P, Taeki, HH. Carranza's. Clinical Periodontology. $10^{\text {th }} \mathrm{Ed}$. St. Louis. Saunder Elsevier; 2006. h. 57-70.

9. Junqueira LC, Carneiro J. Histologi Dasar : Teks \& Atlas, Tambayong J (penterjemah) Ed 10, Jakarta: EGC; 2007. h. 134-6.

10. Widyastuti R. Periodontitis: diagnosis dan perawatannya. Jurnal Ilmiah dan Teknologi Kedokteran Gigi 2009; 6(1): 20-5.

11. Ekaputri S, Masulili SC. Cairan sulkus gingiva sebagai indikator keadaan jaringan periodontal. Majalah Kedokteran Gigi 2010; 17(1): 12-15.

12. Kajiya M, Giro G, Taubman MA, Han X, Mayer MPA, Kawai T. role of periodontal pathogenic bacteria in RANKL-mediated bone destruction in periodontal disease. J Oral Microbiol 2010; 2: 5532-48.

13. Kresno SB. Imunologi. Jakarta. Badan Penerbit FKUI; 2010. h. 95, 215-25. 
14. Bartold PM, Cantley MD, Haynes DR. Mechanism and control of pathologic bone loss in periodontitis. Periodontology 2000 2010; 53: 55-69.

15. Carranza FA, Takei HH. Bone loss and patterns of bone destruction. In : Carranza FA, Forrest JL, Kenney EB, Klokkevold PR, Newman MG, Novak MJ, Preshaw P, Taeki HH. Carranza's Clinical Periodontology. $10^{\text {th }}$ Ed. St. Louis. Saunder Elsevier; 2006. h. 456-60.
16. Bascones-Martinez A, Munoz-Corcuera M, Noronha S, Mota P, Bascones-Ilundain C, CampoTrapero C. Host defence mechanisms against bacterial aggression in periodontal disease: basic mechanism. Med Oral Patol Oral Cir Bucal 2005; 14(12): e680-e685.

17. Page RC. The pathobiology of periodontal disease may affect systemic diseases: inversion of paradigm. Ann Periodontol 1998; 3: 108-20 